\title{
Breeding phenology and nesting habitat characterisation of the San Andres Vireo (Vireo caribaeus)
}

\author{
CAMILA GÓMEZ-MONTES and MARIA ISABEL MORENO
}

\section{Summary}

We describe the breeding phenology and nesting habitat characteristics of San Andres Vireo Vireo caribaeus for the breeding season of 2004. Nest monitoring of colour marked individuals took place in three major vegetation types (dry scrubland, mangrove forest and dense forest) on San Andrés Island, Colombia. In all of them, vegetation structure variables were measured and compared using principal components analysis. A courting song was recorded and its sonograms are presented here. Nineteen nests were monitored between January and June, of which $80 \%$ were found in dry scrubland, 10\% in mangrove forest and 10\% in dense forest. Nesting stages were found to be similar in length to those known for other vireos. Nest construction took $6 \pm$ 0.87 days (mean \pm SD), clutch size was $2 \pm 1$ eggs (mean \pm SD), incubation took $17 \pm 2.47$ days $($ mean $\pm \mathrm{SD}$ ), and nestling period was $9 \pm 1.57$ days (mean $\pm \mathrm{SD}$ ). Fourteen nestlings fledged from successful nests $(53 \%)$ and post fledging care was sustained for $28 \pm 4.17$ days (mean \pm SD). Vireo nests were found in sheltered dry areas, characterized by a thick cover of dead leaves on the ground $(\geq 60 \%$ ) and a low canopy height (mean $=5 \mathrm{~m}$ ) but providing $60 \%$ cover over the nest. Nest trees were healthy plants and $75 \%$ of the nests hung from east-facing forked branches at a height of $0.73^{-2.0} \mathrm{~m}$. Nesting trees were typically surrounded by 3-5 species of fleshy fruit plants fed to chicks. Conservation of the vireo would benefit from maintenance of traditional land use practices in dry scrubland on the island and protection or special management of some areas of this habitat should be considered.

\section{Resumen}

Describimos la fenología reproductiva y el hábitat de anidación del Vireo de San Andrés Vireo caribaeus para la estación reproductiva del 2004. Monitoreamos nidos de individuos marcados con anillos de color en tres tipos de vegetación representativos (bosque seco ralo, bosque de manglar y bosque denso) en la isla de San Andrés - Colombia y, en todos, medimos variables de la estructura de la vegetación y utilizamos un análisis de componentes principales para su comparación. El canto de cortejo fue grabado y los sonogramas se presentan aquí. 19 nidos fueron monitoreados de enero a Junio, de los cuales $80 \%$ se encontraron en bosque seco ralo, 10\% en manglar y 10\% en bosque denso. Los periodos de anidación fueron similares a los conocidos para otras especies de Vireo. La construcción del nido tomó $6 \pm 0.87$ días (media $\pm \mathrm{DE}$ ), el tamaño de la puesta fue de $2 \pm 1$ huevos (media $\pm \mathrm{DE}$ ), la incubación fue de $17 \pm 2.47$ días (media $\pm \mathrm{DE}$ ) y el periodo de pichones duró $9 \pm 1.57$ días (media $\pm \mathrm{DE}$ ). Catorce pichones volaron de los nidos exitosos $(53 \%)$ y el cuidado post volantón continuó por $28 \pm 4.17$ días más (media $\pm \mathrm{DE}$ ). Los nidos de vireo fueron encontrados en áreas cubiertas y secas caracterizadas por una alta cobertura de hojas secas en el suelo ( $\geq 60 \%$ ) y una altura baja del dosel ( $5 \mathrm{~m}$ promedio) pero proveyendo $60 \%$ de cobertura sobre el nido. Los árboles del nido fueron plantas saludables y $75 \%$ de los 
nidos colgaban de horquetas en dirección Este a una altura de 0.73 a $2.0 \mathrm{~m}$. Los árboles del nido estaban rodeados por tres a cinco especies de plantas con frutos carnosos que sirvieron de alimento para los pichones. La conservación del vireo se beneficiaría al mantener el uso tradicional de la tierra en el bosque seco ralo y se debe considerar la protección o manejo especial de algunas áreas de este hábitat en San Andrés ya que en este momento carecen de la misma.

\section{Introduction}

The San Andres Vireo Vireo caribaeus or Chincherry, as it is locally known, is endemic to San Andrés Island in Colombia. The species is listed as 'Vulnerable' due to restricted range and susceptibility to stochastic events (IUCN 2006). Despite this, there is a lack of information on the species' breeding seasonality and its habitat preferences during this period. Previous descriptions of San Andres Vireo nests are based on casual encounters and are limited to anecdotal descriptions. Barlow and Nash (1985) described two nests of the San Andres Vireo, found in April 1972 and June 1983, as being typical of the Vireonidae: an open cup hanging from a forked branch. They also reported the egg measurements and morphology; that both sexes participated in parental care; and commented on their territory size being no greater than 0.5 ha. These nests were found in mangrove and in dry scrubland. Rosselli (1998) extended the breeding season with his encounter of a nest in February 1997, in dry scrubland, and complemented the existing information with his observations on nestling diet noting that adults fed chicks with unidentified "small orange fruits" as well as with a variety of arthropods. Finally, Moreno and Devenish (2003) report encountering two nests in March 2001, in dry scrubland and separated only $20 \mathrm{~m}$ from each other.

Those studies formed the basis on which to start defining the species' breeding chronology. In this paper, we aimed to confirm the earlier information, give details on the breeding phenology including song, territory size and nesting period duration and carry out a characterization of the species' breeding habitat to determine relationships between vegetation structure and nest placement. All this was done with the aim of providing crucial information for a better understanding of how to protect this vulnerable species and to develop conservation strategies.

\section{Methods}

Study site. - San Andrés $\left(12^{\circ} 2 \mathrm{O}^{\prime} 55^{\prime \prime}-12^{\circ} 35^{\prime} 37^{\prime \prime} \mathrm{N} ; 81^{\circ} 40^{\prime} 49^{\prime \prime}-81^{\circ} 43^{\prime} 49^{\prime \prime} \mathrm{E}\right)$ is a $15 \mathrm{~km}^{2}$ coralline island in the Colombian Caribbean. Distance to the nearest continental shore is $290 \mathrm{~km}$ to the coast of Nicaragua. Most of the Island's 70,00o inhabitants live in three urban areas located at the north end 'El Centro', in the middle ridge 'La Loma' and on the south east coast 'San Luis', with the northern one being in fact overpopulated (See figure 1). The three major vegetation types on San Andrés, are 1) Dry scrubland - 31\% land cover, not protected: an open canopy secondary forest with dense shrub strata and abundant deciduous plants adapted to drought and scattered with old plantation crops such as Coconut Cocos nucifera and Cotton Gossypium barbadense; 2) Mangrove forest $-6 \%$ land cover, protected: permanently flooded areas with either Black, Red or White Mangrove (Avicennia germinans, Laguncularia racemosa and Rhizophora mangle respectively) according to location and salinity; and 3) Dense forest $-4 \%$ land cover, protected: once the native vegetation covering the island, with giant Ceiba Ceiba pentandra and Cedar Cedrela odorata trees and large underground water reserves (Gobernación departamento Archipiélago de San Andrés, Providencia \& Santa Catalina 2003). Patches of the described vegetation types are interwoven with areas of urban settlements and open farmland.

Breeding seasonality and nest monitoring. - Field work took place from mid-January to the end of June 2004.We followed the Breeding Biology Research and Monitoring Database (BBIRD) field protocol (Martin et al. 1997) with a few adaptations to particular site conditions that will be mentioned where appropriate. As the species is common throughout the island, vegetation types 


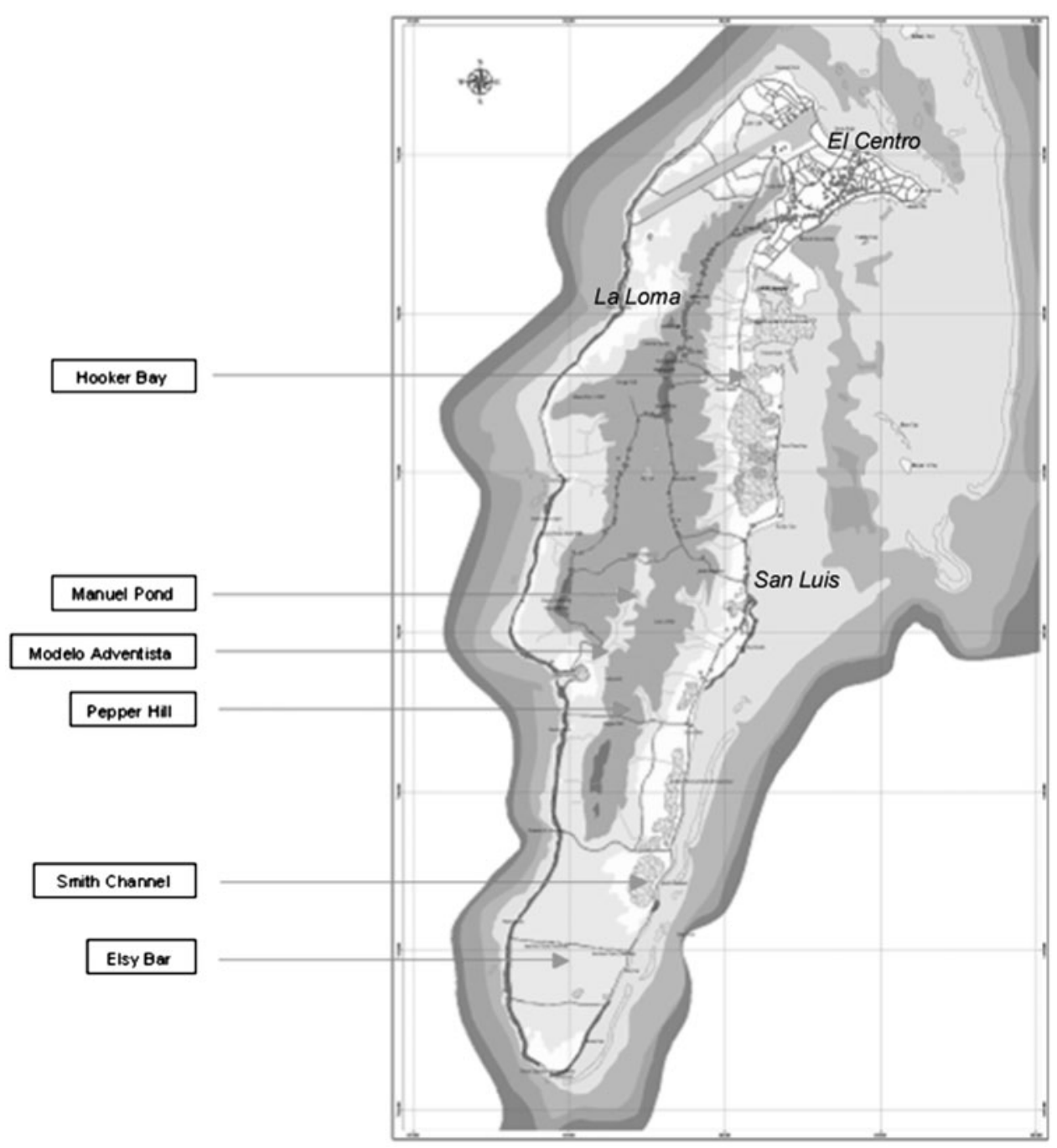

Figure 1. Map of San Andrés Island showing major vegetation types and placement of the six study plots. Mangrove: Hooker Bay and Smith Channel, Dry Scrubland: Pepper Hill and Elsy Bar and Dense Forest: Manuel Pond and Modelo Avdentista.

were selected based on previous reports of high abundance for the species (Rosselli 1998, Moreno and Devenish 2001). Six 200 x $200 \mathrm{~m}$ study plots, two per vegetation type, were set up randomly in order to determine preferred nesting habitat type (Figure 1 ). The plots were mapped on a grid and flagged at $20 \mathrm{~m}$ intervals and were more than $200 \mathrm{~m}$ apart in all cases to guarantee independence. Each study plot was initially visited every four days from o6hzo to Irhoo. Activities during different visits included systematic nest search, song recording, territory mapping of colour marked individuals and random observations. Once the breeding season started, effort was doubled to two visits per day (each to a different plot): $06 \mathrm{~h}_{30} \mathrm{O}-1 \mathrm{I}$ hoo and

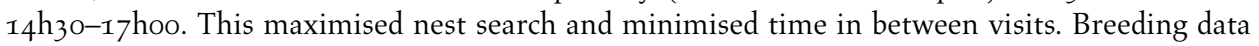


were collected using nest cards on which all observations of the nests were recorded systematically e.g. finding method, nest stage, number of eggs, adult behaviour, weather (see Martin et al. 1997).

Mating songs were taped with a reporter-type cassette recorder (SONY TCM-20oDV) and an adapted Aiwa microphone. Recordings were digitalized and sonograms were produced and analysed using the Syrinx sound analysis program (Burt 2004). Given that these songs were not previously heard in other visits to the Island, and that song is usually a good indicator of breeding activity in Neotropical birds, they were taken as a behavioural indication of the start of the breeding season (Skutch 1950, Barlow and Nash 1985, Gomez, pers obs). Capture data, especially presence of developed brood patch and cloacal protuberance, were also complementary and confirmatory indicators of the start of the breeding season.

Colour ringing and territory mapping using playback response and repeated observations of marked and unmarked birds, within each study plot, were used to determine territory size and nest ownership (Martin et al. 1997). Mist nets were deployed near or inside territories and birds were sound lured to them. Caution was taken to disturb the vegetation as little as possible, so naturally open areas and trails were used for mist nets and only minimum cutting took place to open other spaces as necessary. In some cases, this reduced the number of individuals that could be captured per habitat type due to lack of appropriate spaces to set up mist nets without changing the vegetation structure. Males and females show no plumage differences so they were not sexed in the hand if there were no signs of either a developed cloacal protuberance or brood patch, although males in this species present a partial brood patch. Sampling effort was 121 nethours in each vegetation type and approximately 240 hours of field observations per vegetation type. Nest search parameters and breeding behaviour queues included location and following of females, observation of behaviours such as courting, copulations and 'nest dance', collection of nest material, scanning for potential nest sites, increase in foraging speed, food carrying, etc (see Martin and Geupel 1993).

Nesting habitat characterisation - $5 \mathrm{~m}$ circular vegetation plots, centred at each nest, were marked and systematically measured for comparison of nesting habitats. Within these plots, 12 variables were measured to describe the nest's physical location in the vegetation and 29 additional variables were measured to describe the vegetation and general structure surrounding the nests. Table I summarises the variables measured in each case with indication of units where appropriate. Measurements were taken with measuring tapes, a home made densiometer (for forest cover measurements), and through ocular estimates (ground cover). For further measurement details and methodologies see the BBIRD protocol (Martin et al. 1997).

Additionally three $10 \mathrm{x}$ 10 $\mathrm{m}$ subplots were marked within each study site to compare plant composition and abundance for each habitat type. Plants that could not be identified in the field were taken back to the lab for classification. Samples were left in the Island's Botanical Garden collection.

Statistical Analyses - Variables from nest location and vegetation around the nest were analysed using principal components analysis. The rotation method used was Varimax with Kaiser normalisation. This type of rotation is the one most commonly used and is applicable here because it maximised the variance of the loadings. Resulting coefficients were standardised and tested for sphericity using Bartlett's test. Significance between variables was taken as $<0.01$. Criteria to choose the most significant components were based on association values and eigenvalues with a correlation score greater than $|0.5|$. The resulting components were renamed and interpreted following methods in Hair et al. (1998), then correlated with the number of nests found in each habitat to determine relationships between vegetation structure and nest placing.

Cluster analysis, using average linkage between groups, was applied to the vegetation data from the $10 \times 10 \mathrm{~m}$ plots to prove similarities among and within different vegetation plots. A dendrogram was constructed to visualize these similarities. All the above analyses were carried out using SPSS version 12.0 for Windows.

Differences in nest placing and habitat preferences were confirmed with Chi squared analysis of sampling effort at a significance level of $P<0.05$. 
Table 1. List of variables measured to describe nest location and vegetation around nests. Details of measurements and methodology to take each one can be seen in the BBIRD protocol (Martin et al, 1997).

\begin{tabular}{|c|c|c|}
\hline Variables describing nest's physical location & Mean & SD \\
\hline Nest height $(\mathrm{m})$ & 1.24 & 0.49 \\
\hline \multicolumn{3}{|l|}{ Specie of nest plant/tree } \\
\hline Plant height (m) & 2.60 & 1.38 \\
\hline \multicolumn{3}{|l|}{ Plant health } \\
\hline DBH of nest plant $(\mathrm{cm})$ & 2.67 & 2.09 \\
\hline \multicolumn{3}{|l|}{ Objects concealing nest } \\
\hline \multicolumn{3}{|l|}{ Nest orientation } \\
\hline No of supporting branches & 3.00 & 0.00 \\
\hline Diameter of supporting branch $1(\mathrm{~cm})$ & 0.77 & 0.60 \\
\hline Diameter of supporting branch $2(\mathrm{~cm})$ & 0.48 & 0.17 \\
\hline Diameter of supporting branch $3(\mathrm{~cm})$ & 0.38 & 0.14 \\
\hline Nest distance from stem (m) & 0.90 & 1.13 \\
\hline Nest distance to foliage edge (m) & 0.30 & 0.14 \\
\hline$\%$ side cover by vegetation & 44.6 & 12.9 \\
\hline Variables describing $5 \mathrm{~m}$ circular plots centered at the nests & Mean & SD \\
\hline Average canopy height (m) & 7.27 & 2.92 \\
\hline$\%$ Canopy cover & $47 \cdot 7$ & 21.3 \\
\hline \multicolumn{3}{|l|}{ Dominant species in Canopy } \\
\hline Ground slope $\left({ }^{\circ}\right)$ & 0.10 & 0.43 \\
\hline$\%$ of ground covered by leaves & 70.6 & 22.5 \\
\hline$\%$ of ground covered by rock & 2.33 & $5 \cdot 45$ \\
\hline$\%$ of ground covered by moss & 0.71 & 1.32 \\
\hline$\%$ of ground covered by wood & 11.2 & 7.27 \\
\hline$\%$ of ground covered by soil & 9.87 & 12.1 \\
\hline$\%$ of ground covered by water & 5.10 & 18.3 \\
\hline Depth of organic matter $(\mathrm{cm})$ & 6.99 & 8.77 \\
\hline \multicolumn{3}{|l|}{ List of all the other plant species present in plot } \\
\hline \multicolumn{3}{|l|}{ Species of nearest shrub } \\
\hline Distance to nearest shrub (m) & 0.69 & 0.50 \\
\hline Height of nearest shrub (m) & 1.01 & 0.53 \\
\hline Maximum width of nearest shrub (m) & 0.39 & 0.15 \\
\hline \multicolumn{3}{|l|}{ Species of nearest tree } \\
\hline Distance to nearest tree $(\mathrm{m})$ & 2.06 & 1.41 \\
\hline Height of nearest tree (m) & 6.59 & 2.51 \\
\hline DBH of nearest Tree $(\mathrm{cm})$ & 52.3 & 44.2 \\
\hline Average crown width (m) & $3 \cdot 57$ & 1.63 \\
\hline \multicolumn{3}{|l|}{ Species of nearest snag } \\
\hline Distance to nearest snag (m) & 1.52 & 1.04 \\
\hline Height of nearest snag (m) & 2.12 & 0.86 \\
\hline DBH of nearest snag $(\mathrm{cm})$ & 1.64 & 0.96 \\
\hline Number of stems $<2.5 \mathrm{~cm}$ & $59 \cdot 9$ & 45.1 \\
\hline Number of stems $>2.5 \mathrm{~cm}<8.0 \mathrm{~cm}$ & $9 \cdot 50$ & 5.87 \\
\hline Number of stems $>8.0 \mathrm{~cm}<23 \mathrm{~cm}$ & 2.83 & 4.58 \\
\hline Number of stems $>23 \mathrm{~cm}$ & 0.50 & 0.64 \\
\hline
\end{tabular}

\section{Results}

Breeding behaviour and territory mapping - A total of 64 individuals were colour marked ( 25 in dry scrub, 19 in mangrove and 21 in dense forest). The differences in the number of individuals captured per vegetation type for the same trapping effort were not significant $(P=0.65)$. Of these, 
31 pairs were re-sighted and monitored in this study. 22 additional unmarked birds were followed and stimulated with playback to compare their territory sizes with those of marked birds but due to the inability to recognize individuals these territories were not included in the analyses. Breeding territories of the colour marked individuals were found to be (mean \pm SD) $0.22 \pm 0.07$ ha $(n=31)$ and were defended by males. We recorded agonistic encounters between males that intruded onto territories and these included chasing and display of aggressive and stress calls. Playback caused the same response from the territory owner that a real intruder did. Females, on the other hand, were silent and inconspicuous. We did not register any aggressive encounters by or between females in more than 700 hours of observation. This behaviour was an aid to sexing individuals in the field.

We found that males of the San Andres Vireo have specific courting songs which they perform solely in front of their mate ( $100 \%$ of six types of courting songs heard). Courting song (as we denominated it) differs from other vocalizations, such as those related to territory defence and neighbour communication, because it is longer and more complex, as revealed by sonogram analysis (Figure 2). Also, these songs were not recorded before the 15 March and thus prior to the peak in nest construction (see below). Males mix chatting and whistling calls and include high pitched trills in unique individual series that are repeated at uniform time intervals. These songs are accompanied by behaviours such as hopping around in front of the mate and fluffing of breast and tail feathers. Females collected nest material and built nests alone while their mate sung nearby. The pair was never far apart, they both emitted simple calls to locate each other in the dense vegetation.

Nesting phenology - The breeding season of the San Andres Vireo commenced in mid-March (with the first courtship displays detected from 15 March) and continued until June. Developed brood patches and cloacal protuberances were first recorded on 23 March and the first nest building observation was made on 31 March. Nineteen nests were found from January to June 2004, with a peak of findings in April (12 nests). The last nest was found on 6 June. Under equal effort, fifteen of these nests were found in dry scrubland, two in dense forest and two in mangrove forest, thereby indicating a significant preference for dry scrubland $\left(X_{2}^{2}=17.8\right.$, $P=$ o.001). Nests were found in different stages: five during nest construction, seven during incubation, three in nestling period, two predated and two empty (Figure 3 ).

Nest construction took $6 \pm 0.87$ days $(n=5)$, clutch size was $2 \pm 1$ eggs $(n=10)$ and incubation took $17 \pm 2.47$ days $(n=5)$. All these data are expressed as mean \pm SD. Adults sat on newly hatched chicks the first day and after that they visited the nest and stood on its side while feeding the young. Nestling period was $9 \pm 1.57$ days $(n=7)$. Adults took turns to approach the nest with food. In three fifths of these feeding visits (of seven pairs observed during 43 visits), parents brought fruit rather than insects to feed their chicks. Plant species fed to nestlings were identified as: Randia gaumeri (Rubiaceae), Albertia edulis (Rubiaceace) locally named "SulSul", Casearia sp., (Flacourtiaceae) locally named "Maká" and Rauvolfia hirsuta (Apocynaceae) (using Cruz and Lowy 1992, Gonzales et al. 1995). Fourteen nestlings fledged from successful nests (53\% success rate) and post-fledging care was sustained for a mean \pm SD of $28 \pm 4.17$ days $(n=6)$.

Of the $47 \%$ monitored nests that failed, the majority (five of nine) did so during the incubation period due to egg infertility or to clutch abandonment for unknown reasons. Failure due to predation was only detected during the post-hatching period not before (two of nine). Two nests were abandoned before they were completely constructed or apparently finished but without eggs. We did not recorder re-nesting attempts either by pairs that failed or by successful pairs. As nest parasites are not present on the island these were not a threat or source of nest failure.

Nesting habitat characterisation - Cluster analysis of the $10 \mathrm{x} 10 \mathrm{~m}$ vegetation subplots produced three distinct groups, confirming the expected differences between vegetation types: mangrove forest, dense forest, and dry scrubland. The analysis resulted in high similarity within the same vegetation groups and clear differentiation between different ones.

Principal components analysis collapsed the $5 \mathrm{~m}$ plot vegetation variables into three components, with fourteen variables that accounted for $80 \%$ of the variation in nest vegetation 

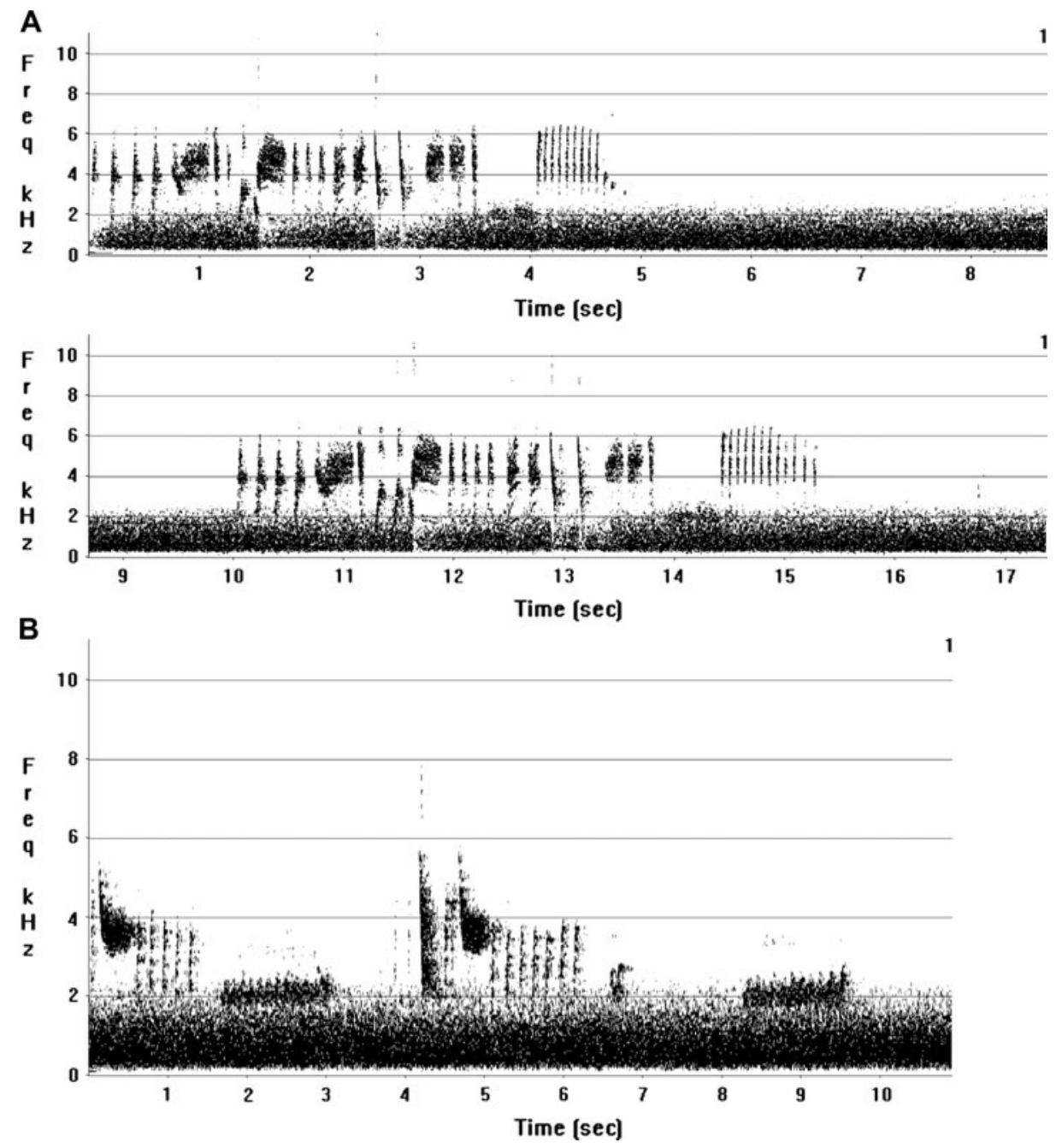

Figure 2. Spectrogram comparison of San Andres Vireo vocalizations. A. Courting song with its complex series of trills and chirping notes repeated at uniform time intervals (A. cont) and B. The characteristic dialogue between two neighbouring male San Andres Vireos: a simple series of short calls.

structure (Figure 4). Table 2 shows the three factors and the variables they contain with their corresponding correlation scores. Only variables with a correlation value greater than or equal to $|0.5|$ were taken into account for further interpretation. Bartlett's sphericity test was significant $P<0.001\left(X_{406}^{2}=1,099\right)$ and Kaiser Meyer's Index was 0.35 .

According to the variables contained in each component, they were named as follows, I) Ground cover component, 2) Nearest tree component and 3) Structure around nest component. Correlation between number of nests and each of the components, resulted in common patterns shared by $60-80 \%$ of the nests $(n=19)$. Nests were placed on average $1.24 \pm 0.49 \mathrm{~m}$ above the 


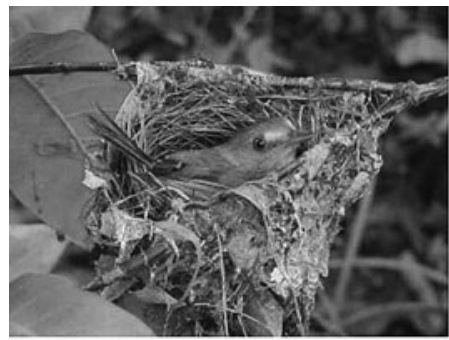

A

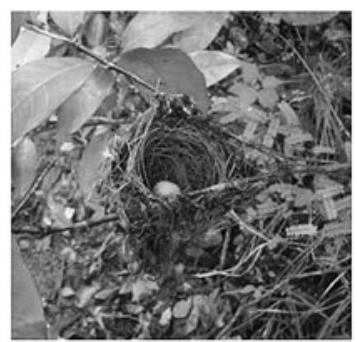

B

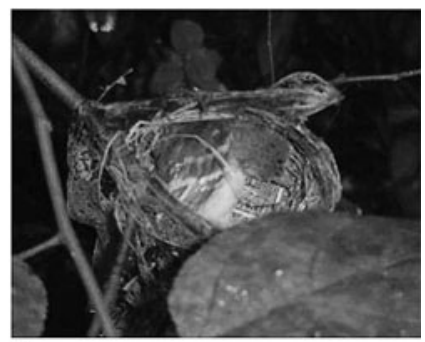

C

Figure 3. Different nesting stages of the San Andres Vireo. A. Incubating male. B. Nest with one egg hanging from a forked branch. C. Nestling.

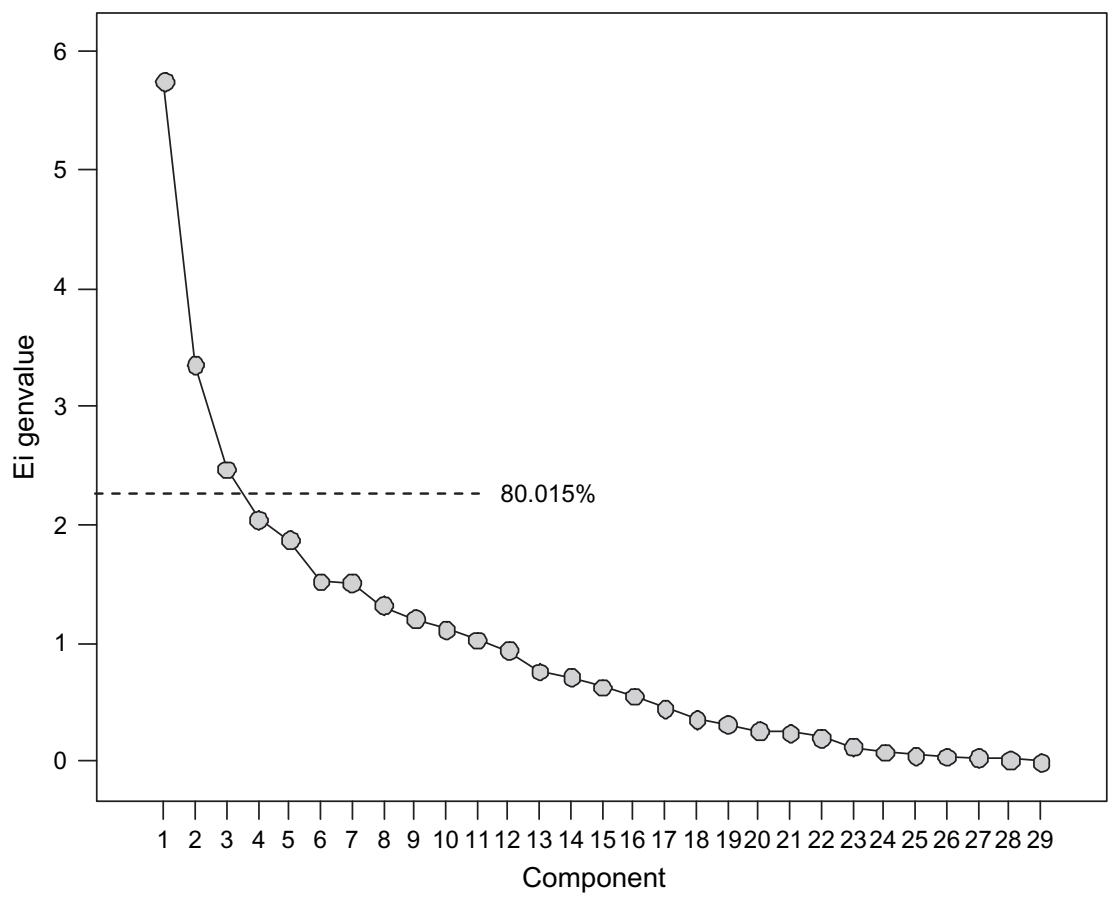

Figure 4. Eigenvalues for each of the components extracted from the $5 \mathrm{~m}$ plot vegetation data of San Andres Vireo nests. The first three components account for $80.015 \%$ of the variability of the data and so were the ones selected for analysis.

ground $(n=19)$ and in dry places with high $(\geq 60 \%)$ dead leaf cover. $75 \%$ of 19 nests hung from east-facing forked branches ( $\geq 1 \mathrm{~cm}$ in diameter). The nest trees were typically (100\% of 19 nests) healthy plants, either woody shrubs or young trees of $2.59 \pm 1.38 \mathrm{~m}$ height. $83 \%$ of the nests were located in sheltered areas surrounded $(\geq 5 \mathrm{~m})$ by food resources $(3 \pm 0.94$ fruit plants fed to chicks around each nest $(n=19))$. There was a relatively large sized tree $(\geq 20 \mathrm{~cm} \mathrm{dbh})$ at least $5 \mathrm{~m}$ from the nest providing $60 \%$ canopy cover on average. 
Table 2. Three factors extracted by the principal components analysis and the variables they contain. Correlation scores for each variable are also shown.

\begin{tabular}{llcl}
\hline Factor & Variable & Correlation & Associated characteristic \\
\hline 1 & \% of ground covered by water & 0.91 & Ground Cover \\
& \% of ground covered by leaves & -0.89 & \\
Depth of organic matter $(\mathrm{cm})$ & 0.85 & 0.81 & \\
Average canopy height $(\mathrm{m})$ & -0.49 & Nearest tree \\
Height of nearest shrub (m) & 0.87 & \\
Average crown width (m) & 0.8 & \\
& Height of nearest tree $(\mathrm{m})$ & 0.74 & \\
DBH of nearest Tree (cm) & 0.55 & Surrounding structure \\
Distance to nearest tree (m) & 0.44 & \\
Species of nearest tree & 0.75 & \\
Dominant species in Canopy & -0.67 & \\
\% of ground covered by soil & 0.57 & \\
Distance to nearest shrub (m) & 0.56 & \\
\% Canopy cover & & \\
\hline
\end{tabular}

\section{Discussion}

This study sheds more light on the breeding ecology of the San Andres Vireo and revealed more of its needs during this critical period of the life cycle. It confirms a defined breeding season starting as early as February and ending in June, in agreement with the past nest records for the species, a single nesting attempt with a small clutch of two eggs and preference for dry scrubland during the nesting period (Barlow and Nash 1985, Rosselli 1998, Moreno and Devenish 2001).

Breeding behaviour - Courting songs, nests found in early stages (and through various searching methods), developed brood patches and cloacal protuberances confirmed the start of the breeding season. None of these indicators were detected before mid-March, despite 120 net hours, more than 200 hours of direct observation and 4 hours of song recording of birds prior to this date, so we regard them as accurate estimations of the starting dates of breeding activity in 2004; however, our results should still be compared with future data for validation. The Puerto Rican Vireo V. latimeri, another single island endemic, has a similar breeding season, lasting from 2.5 to 3.5 months and starting as early as 22 March (Woodworth 1997).

Territory sizes for the San Andres Vireo were found to be much smaller than the 0.5 ha previously suggested by Barlow and Nash (1985) and by Moreno \& Devenish (2001). Indeed, our finding is that territories, during the breeding season at least, are roughly half this size. One possibility is that during the breeding season territories are clustered together in the preferred locations for nesting, though more study is needed to confirm this.

The courting displays that we report here have been described before for other species of vireo as well. Bradley (1980), for example, reported that the White-eyed Vireo V. griseus shows 'discrete and rambling songs' accompanied by similar behaviours to those we observed, and Woodworth (1997) observed that males rather than females were the ones involved in aggressive encounters during territory defence in the Puerto Rican Vireo. Detailed research on the species' song will surely reveal a great variety of vocalisations with interesting ecological and evolutionary implications.

Nesting phenology - Nesting period duration was not very different from that reported for other species of vireos except for a prolonged fledging period of 28 days compared to $10-16$ in North American vireos (Graber 1961, Wells and Kus 2001, Zeller et al. 2001). Our nest failure percentage of $47 \%$ must be viewed with caution due to our small sample size, but it is not very different from failure percentages detected for other species such as the White-eyed Vireo, Bell's Vireo V. bellii and Red-eyed Vireo V. olivaceous (Nolan 1963). There are not many examples in 
the literature of nest success for tropical species, although it has been reported that for 71 species in the lowland forest of central Panama, failure rates are $43-92 \%$, a figure that overlaps with that obtained in this study and with those for similar species in North America (Robinson et al. 2000).

Surprisingly, the major cause of nest failure was abandonment during incubation whilst other studies such as Robinson et al. (2000) have found that predation and nest parasitism are usually the major causes of nest failure for tropical species. There are no vertebrate nest parasites on the island though the Mangrove Cuckoo Coccyzus minor and the Tropical Mockingbird Mimus gilvus, both resident on San Andrés, were seen predating Vireo chicks in the nest. Species of these genera have also been reported as nest predators in Puerto Rico (Woodworth 1997). Black Rats Rattus rattus might predate on eggs and chicks, as well as Boas Boa constrictor, the only snake on the island large enough to do so. Possible predation by other recently introduced species such as the Great-Tailed Grackle Quiscalus mexicanus and the Tegu Lizard Tupinambis teguixin need to be confirmed and quantified. Given the San Andres Vireo's fairly restricted breeding season and small clutch sizes, its reproductive potential must be considered low and therefore the population is expected to have a limited ability to recover from perturbation. Consequently, the effects of introduced predators on the island and environmental changes should be closely monitored as well as any changes in population size (Pimm 1991, Woodworth 1997).

Habitat characterisation - The principal components analysis showed structural patterns that might play an important role during site selection for nest placement in the San Andres Vireo. First was the general importance of ground cover, which appears to highlight a major difference between the habitat types more than a particularity the species would choose. However, there may be ecological advantages to having a nest in places with thick dead leaf cover, i.e. insect prey abundance and sound warning of predator presence (Rands 1988). Orientation of the nests to the East may be a behavioural strategy to either avoid or make the most of certain environmental and/or microhabitat conditions. Nest orientation has been found to determine nest success to some extent in Cactus Wrens Campylorhynchus brunneicapillus (Austin 1974), whilst Tree Pipits Anthus trivialis build their nests facing east to maximize warming in the morning sun and shelter from WSW winds (Burton 2006). No doubt more study is needed to confirm the effect that east-oriented nests have on breeding success of the San Andres Vireo as well as more examples of such behaviour in tropical species for further comparison.

Plants surrounding the nest included several of the species that are fed to chicks. It is an interesting particularity of this species to have such a fruit-based diet for nestlings. Although it is common to find birds that vary their diet at different stages of their life cycles, it has been found that most species seek to give more protein-rich food to their chicks in order to accelerate growth and time to leaving the nest (Morton 1973). It is also possible that to some extent, the exceptionally high rate of fruit feeding during this particular year reflects a bad insect year on the island for unknown reasons. However, the fact that most nests had some of these plant species surrounding them would appear to indicate an active preference for placement in such sites and may be one of the reasons vireos prefer this habitat over the others. There were no specific examples in the literature that we could find, regarding a similar dietary particularity in other vireos. Study of the phenology and distribution of these fruiting plants would be useful in order to confirm if they affect the timing of reproduction, nest placement and success.

Management implications - There are several management implications concerning habitat requirements of the San Andres Vireo during the breeding season. First, unlike mangrove forest and dense forest, the dry scrubland, the preferred habitat for nest placement, is not protected on the island. Dry scrubland cover is destined for agriculture on the island's 17 year development plan $(2003-2020)$ and so it could potentially change drastically in structure depending on the type of agricultural practice implemented. Traditional land use by communities on the island is based on small scale growing of varied crops in areas of land usually less than 2 ha surrounded by live fences (Gomez pers obs). Many of the plant species that grow on the dry scrubland have medicinal uses as well and so they are left within the planted areas for use (Gonzalez et al. 1995, 
Maya et al. 1998). The result is a heterogeneous landscape providing a gradual transition between managed and natural habitats that are used by the vireos and many other bird species. Live fences are extensively used as corridors by the San Andres Vireo and most other island species as well (Moreno \& Devenish 2001, Gomez, pers. obs.).

Maintaining traditional land use instead of modern large scale monoculture should benefit the San Andres Vireo as well as other bird species on the Island. Special protection of some dry scrubland areas, as well as encouraging the communities to avoid cutting down or burning scrub during the main breeding season, should be considered by land managers and environmental authorities to prevent drastic changes of habitat structure and composition that may have detrimental effects on the population of San Andres Vireo.

\section{Acknowledgements}

We thank Universidad Nacional sede San Andrés, for providing logistical support during the field working months on the Island. Special thanks also to the ProAves Migrant Monitoring and Conservation Programe research team on San Andrés, Dr. Pablo Stevenson for his insights and to Dr. Nicholas Bayly and two independent referees for the comments that improved this manuscript. This study was financed by Iniciativa de Especies Amenazadas - IEA, an alliance between Conservation International-Colombia, Fundación Omacha and Fondo para la Acción Ambiental y la Niñez.

\section{References}

Austin, G. T. (1974) Nesting success of the Cactus Wren in relation to nest orientation. Condor 76: 216-217.

Barlow, J. C. and Nash, S. V. (1985) Behaviour and nesting biology of the St. Andrew Vireo. Wilson Bull. 97: 265-412.

Bradley, R. A. (1980) Vocal and territorial behavior in the white eyed vireo. Wilson Bull. 92: 302-311.

Burt, J. (2004) Syrinx sound analysis program, Version 2.3s. <www.syrinxpc.com>. Downloaded July 2004.

Burton, N. H. K. (2006) Nest orientation and hatching success in the Tree Pipit (Anthus trivialis). J. Avian Biol. 37: $312-317$.

Cruz, J. N. and Lowy, P. D. (1992) Contribución al conocimiento de la flora vascular terrestre del archipiélago de San Andrés y Providencia. Tesis de Biología. Bogotá: Universidad Nacional de Colombia.

Gobernación Departamento Archipielago de San Andrés Providencia y Santa Catalina. (2003) Plan de Ordenamiento Territorial San Andrés Isla 2003 - 2020. Documento Técnico de Soporte.

Gonzales, F., Díaz, J. N. and Lowy, P. D. (1995) Flora ilustrada de San Andrés y Providencia, con énfasis en las plantas útiles. Bogotá: Convenio SENA - Universidad Nacional de Colombia. Instituto de Ciencias Naturales.

Graber, J. W. (1961) Distribution, habitat requirements and life history of the black capped Vireo (Vireo atricapilla). Ecol. Monogr. 31: 313-336.

Hair, J. F., Anderson, R. E., Tatham, R. L. and Black, W. C. (1998) Multivariate data analysis. Englewood Cliffs, New Jersey: Prentice Hall.

IUCN. (2006) Vireo caribaeus. In 2006 IUCN Red List of threatened species. $<$ www.iucnredlist.org $>$. Downloaded on OI June 2007.

Martin, T. E. and Geupel, G. R. (1993) Nestmonitoring plots: methods for locating nests and monitoring success. J. Field Ornithol. 64: 507-519.

Martin, T. E., Paine, C. R., Conway, C. J., Hochachka, W. M., Allen, P. and Jenkins, W. (1997) BBIRD field protocol. Missoula, Montana, USA: Montana Cooperative Wildlife Research Unit, University of Montana.

Maya, L. A., Arocha, J., Dieck, M., Fredemann, N. S., Jimenez, O., Leal, C., Pomare, L., Rivas, A., Romero, M. D., Serrano, J. F., 
Spicker, J., Vanin, A., Villa, W. and Zuluaga, F. U. (1998) Geografía humana de Colombia tomo IV: Los afrocolombianos. Santa fe de Bogotá: Instituto Colombiano de Cultura hispánica.

Moreno, M. I. and Devenish, C. (2003) Estado y conservación de Vireo caribaeus ave endémica de la Isla de San Andrés. Bogotá: Fauna y Flora Internacional, Instituto de investigación de Recursos Biológicos Alexander Von Humboldt, Instituto de estudios Caribeños- Universidad Nacional sede San Andrés.

Morton, E. S. (1973) On the evolutionary advantages and disadvantages of fruit eating in tropical birds. Am. Nat. 107 (953): 8-22.

Nolan, V. (1963) Reproductive success of birds in a deciduous scrub habitat. Ecology 44: 305-313.

Pimm, S. L. (1991) The balance of nature? Ecological issues in the conservation of species and communities. Chicago: University of Chicago Press.

Rands, M. R. W. (1988) The effect of nest site selection on nest predation in Grey Partridge (Perdix perdix) and Red-Legged
Partridge (Alectoris rufa). Ornis Scand. 19: 35-40.

Robinson, W. D., Robinson, T. R., Robinson, S. K. and Brawn, J. D. (2000) Nesting success of understory forest birds in central Panama. J. Avian Biol. 31: 151-164.

Rosselli, A. (1998) Estudio de la Biología de Vireo caribaeus, Una especie endémica de San Andrés- Colombia. Bogotá D.C: Tesis de grado, Biología. Universidad de los Andes.

Skutch, A. F. (1950) The nesting seasons of Central American birds in relation to climate and food supply. Ibis 92: 185-222.

Wells, J. M. and Kus, B. E. (2001) Least Bell's Vireo surveys and nest monitoring at Anza Borrego Desert State Park in 2000. Final report. San Diego, CA: U.S. Geological Surveys. Western Ecological Research Center. San Diego Field Station.

Woodworth, B. L. (1997) Brood parasitism, nest predation, and season-long reproductive success of a tropical island endemic. Condor 99: 605-621.

Zeller, N. S., Hammerson, G. and Mehlman, D. W. (2001) Species management abstract, Yellow Throated Vireo (Vireo flavifrons). Arlington, VA: The Nature Conservancy.

\section{CAMILA GÓMEZ-MONTES*}

Facultad de Biología, Universidad de Los Andes, Carrera 1 \# 18 A - 10, Bogotá, Colombia.

\section{MARIA ISABEL MORENO}

Fundación ProAves, Carrera 20 \# $36-61$, Bogotá, Colombia.

*Author for correspondence. Current address: Fundación ProAves, Carrera 20 \# 36 - 61, BogotáColombia.e-mail: camilgomo@yahoo.co.uk. 